\title{
Hesablama buludlarında istifadəçilərin biometrik autentifikasiyası üsullarının analizi
}

\author{
Şəfəqət Mahmudova \\ AMEA İnformasiya Texnologiyaları İnstitutu, Bak1, Azərbaycan \\ shafagat_57@mail.ru
}

\begin{abstract}
Xülasə- Müasir dövrdə hesablama buludlarından müxtəlif sahələrdə geniş istifadə olunur. Hesablama buludlarında istifadəçilərin təhlükəsizliyinin təmin edilməsi əsas problemlərdən biridir. Bu işdə hesablama buludlarında təhlükəsizliyin təmin edilməsində biometrik autentifikasiya üsullarından biri olan insanın sifət təsvirlərinə əsasən tanınması üsulları izah edilmişdir. $\mathrm{Bu}$ sahədə olan problemlər araşdırılmışdır.
\end{abstract}

Açar sözlor- hesablama buludları, tohlükosizlik, autentifikasiya, tanınma, sifat tosvirlori, biometrik olamotlor

\section{GİRIŞ}

Hesablama buludu (cloud computing) kompüter texnologiyalarının infrastrukturunun və proqram təminatının bilavasitə şəbəkə mühitində yaradılmasını və istifadə edilməsini təmin edir. Bunların köməyi ilə istifadəçinin məlumatları bulud sistemlərində saxlanılır, emal edilir və nəticələrə baxılması təmin edilir [1].

Hesablama buludları yeni texnologiyadır. İstifadəçi İnternetdən istifadə edərək istənilən yerdən hesablama buludlarında yerləşdirilən öz fayllarına və ya məlumatlarına giriş əldə edə bilir. Hesablama buludlarından istifadənin öz üstünlükləri vardır, məsələn, istifadə olunma qabiliyyətinin yüksək olması, xərclərin az olması və s. Amma, digər tərəfdən bu sahədə təhlükəsizliyin təmin olunmasının bəzi problemləri mövcuddur. Bu haldan biri də icazəli istifadəçinin buluddan istifadə edən zaman tanınmasıdır, belə ki, istifadəçinin hesablama buluduna giriş əldə etməsi üçün autentifikasiyası təmin olunmalıdır [2]. Autentifikasiya - istifadəçi tərəfindən təqdim edilmiş eyniləşdirmə məlumatlarının həqiqiliyinin yoxlanması prosesidir.

Hesablama buludlarında istifadəçilərin biometrik autentifikasiya üsullarından istifadə olunur. Bunlardan biri də sifətin tanınması vasitəsilə təhlükəsizliyin təmin olunmasıdır.

İşdə biometrik autentifikasiya üsulu kimi istifadəçilərin sifətinə görə tanınması vasitəsilə təhlükəsizliyin təmin olunması məsələlərinə baxılmışdır. Hesablama buludlarında insanın sifət təsvirlərinə əsasən tanınması üçün mövcud metodlar analiz edilmiş və bu sahədə olan problemlər araşdırılmışdır.

Şəxsin üzünün tanınması vasitəsilə təhlükəsizliyin təmin edilməsi tədqiqatçıların diqqətini cəlb etmişdi. O tədqiqatların böyük sahəsini əhatə edir. Şəxslərin üzləri vasitəsilə tanınması hüquq-mühafizə orqanlarına böyük kömək edir və onların işində uğurla tətbiq olunur. Polislərin məlumat bazasından şübhəlilərin təsvirlərinə əsasən avtomatik tapılması polisə potensial şübhəli şəxsləri tez zamanda tanımağa kömək edir. Şəxslərin üzlərinə görə tanınmasının proqram təminatında real vaxtda cavab tələb edilir və onu mobil qurğuda tətbiq edir, portativliyi (kompakt) təmin edir.

Son dövrlərdə mobil hesablama buludlarından (MHB) (Mobile Cloud Computing, MCC) da geniş istifadə olunur. MHB-nin artması və şəbəkənin keçirtmə qabiliyyətinin dinamik olması mobil müştərilərin resurslara əlçatan və mühitə uyğunlaşmaq ehtiyacının meydana çıxmasına səbəb olur. Bunlar böyük məlumatlar vasitəsilə emal edilə bilir və bu işdə hesablama buludlarının imkanlarından istifadə edilir [3].

MHB-də mobil qurğulardan istifadə etdikdə çox problemlər meydana çıxır. MHB-də mobil xidmətlər buluda mobil qurğulardan informasiyanın ötürülməsi, emal olunması, orada məlumatların saxlanılması və mobil resursların qarşıya çıxan problemlərinin həlli üçün potensial texnologiya kimi təqdim edilmişdir [4].

\section{II. İSTİFADӘÇİLӘRIN SİFӘTINӘ GÖRӘ TANINMASI VASITOSILӘ TӘHLÜKӘSIZLIYIN TOMIN OLUNMASI}

Şəbəkə mühitində insanın tanınması prosesinin həyata keçirilməsində təhlükəsizliyin təmin olunması əsas məsələlərdən biridir. Müasir dövrdə elmi işlərdə də şəbəkələrdə təhlükəsizliyin təmin olunmasında insanın tanınması haqqında informasiya çoxdur. Yeni qurğuların və texnologiyaların öyrənilməsi prosesi fəal gedir, belə ki, bunlar müxtəlif sahələrdə tətbiq və inkişaf etdirilir. Bu sahə üzrə olan işlərdə şəxslərin sifətinin tanınması sistemləri, gözün qüzehi qişasının skanerləri, barmaqların izlərinin identifikatorları, smart-kartlar, partlayıcı maddələrin aşkar edilməsi sistemləri, radioqurğu və başqa yeni texnologiyalar haqqında məlumat verilir.

İnsan sifətinin cizgiləri, barmaq izləri, əlin forması, səsin parametrləri, gözün qüzehli qişası və $\mathrm{s}$. biometrik xarakteristikalar üzrə elmi-tədqiqat işlərinin aparılması və yeni biometrik identifikasiya sistemlərinin işlənməsi aktual məsələlərdəndir. Müasir dövrdə insan sifətinin tanınması üzrə kompüter axtarış sistemlərinin istifadəsi geniş vüsət almışdır. Şəbəkə mühitində insanın tanınması üçün müxtəlif üsullardan istifado olunur $\mathrm{ki}$, bu da tanınmanın keyfiyyətinin yaxşılaşmasına səbəb olur. Bu ilk növbədə verilənlər bazasının həcmindən də asılıdır. Qeyd edək ki, şəbəkədə müxtəlif 


\section{"Informasiya tohlükosizliyinin aktual problemlori" \\ III respublika elmi-praktiki seminarı, 08 dekabr 2017-ci il}

verilənlər bazaları toplandıqda və onlarda olan yazıların sayı çox olduqda insanın tanınması prosesi daha da çətinləşir.

Təsvirlər əsasında insanın tanınması üçün kompüterin böyük hesablama gücü tələb edilir. Bu sahədə tədqiqatlar şəxslərin üzlərinin ifadələri və jestlərin tanınması daxil olmaqla insanın və kompüterin qarşılıqlı təsirinə və obyektlərin tanınmasına aiddir. Onlayn sosial şəbəkələrdə, məsələn, Twitter, LinkedIn və Facebook-da yüklənən təsvirlərin miqdarı sürətlə artır. Bununla belə, bu sahədə proqramların ciddi çatışmazlığı mövcuddur. İnsanın təsvirləri haqqında məlumatların yayılması təsvirlər yı̆̆ımının böyük analizinin tədqiqatına ehtiyac yaradır. Belə tədqiqatlar rəqabət üçün əsasdır, çünki standart alətlər və prosedurlar böyük məlumat yığınlarının emalı üçün nəzərdə tutulmamışdır. Bundan başqa, təsvirlər mürəkkəb çoxölçülü strukturludur və tanıma üçün mükəmməl hesablama texnologiyaları tələb edir [5].

Müxtəlif sistemlərdə ümumi təhlükəsizliyin təmin olunması əsas məsələlərdən biridir. Bunlardan biri də hava sərnişinlərinin müdafiəsidir - amma aeroportlar bu sahədə bir qayda olaraq bir-birindən asılı olmayaraq müstəqil işləyirlər. Çoxsaylı təchizatçıların işini mövcud yeni texnologiyaların fərdi şəbəkələri yerinə yetirir, belə ki, onların hər biri üçün yeni avadanlığın, bahalı kabel sisteminin quraşdırılmasını tələb edir. Bir çox aeroportlarda müstəqil rabitə şəbəkələrinin say1 o qədər böyükdür ki (bəzən 50-ni ötür), hətta effektiv idarə etməyə onlar tərəfindən mane olunur. Bu şəbəkələrdən bir çoxu çoxsaylı müşahidə kameralarının, rentgen sistemlərinin, yükün skan edilməsi vasitələrinin və giriş nəzarət sistemlərinin düzgün işləməsinə kömək edirlər. Təhlükəsizliyin əlavə sistemlərinin genişləndirilməsi müddətində şəbəkələrin sayı daha çox böyüyür. Vahid biometrik şəbəkənin olmaması aeroportun daxilində və ondan kənarda yerli və federal hüquq-mühafizə orqanlarına informasiyanın ötürülməsini çətinləşdirir.

Hava sərnişinlərinin etibarını qazanmaq üçün təhlükəsizliyin təmin olunmasına aid olan yeni qurğuların kombinasiyasını tətbiq etmək, istehlakçıların etibarını qaytarmaq, həmçinin bunların identifikasiyasını və informasiyanın birgə istifadəsini təmin edən optimallaşdırılmış sistemlərdən istifadə etmək lazımdır.

Aviaşirkətlərin, aeroport administrasiyası və təhlükəsizlik xidməti personalının arasında informasiyanın ötürülməsini təmin edən təhlükəsizliyin təmin olunmasının sürətli əlaqələndirilmiş şəbəkənin genişləndirilməsi həmçinin hüquqmühafizə orqanları tərəfindən, aviaterminal bağlantılarının və uçuŞ reyslərinin möhlətlərinin sayının əhəmiyyətli dərəcədə azalmasının qarşısını almağa icazə verəcək, belə ki, halhazırda hava sərnişinləri bunlardan çox əziyyət çəkirlər.

Biometrik texnologiyalardan təhlükəsizlik sistemlərində geniş istifadə olunur.

Biometrik texnologiyaların əsas üstünlükləri onların yüksək etibarlılığı, icazəsiz girişdən maksimal dərəcədə müdafiənin təminatı və istifadənin sadəliyidir.

Müxtəlif biometrik texnologiyalar mövcuddur:
- gözlərin qüzehli qişası üzrə identifikasiya texnologiyas1;

- səsin identifikasiya texnologiyasi;

- barmaq izləri üzrə identifikasiya texnologiyası;

- olin naxışları üzrə identifikasiya texnologiyası;

- insan sifətinin təsvirə əsasən identifikasiya texnologiyası va s.

Daxili işlər orqanlarında mövcud olan informasiyalar, kriminalistika bankları və məlumat bazaları kifayət qədər dağınıq və əsasən lokal effektlidir. $\mathrm{Bu}$ regionlararası cinayətkarların fəaliyyətinə qarşı mübarizədə müəyyən çətinliklərə səbəb olur. Bu da şübhəlilərin üzə ç1xardılması təcrübəsində axtarışın imkanlarını məhdudlaşdırır, yəni şəxsin identifikasiya prosesi həyata keçmədən sona çatır.

$\mathrm{Bu}$ problemlərin həllində insanın şifahi nitqi və üzünün təsviri kimi biometrik əlamətlərdən də operativ-axtarış məsələlərində aktiv istifadə oluna bilir.

İstənilən insanın üzünün elementləri onun fərdi biometrik xarakteristikalarıdır. Sənədlərdə olan şəkillərdən identifikasiya üçün ən çox geniş istifadə olunur və bunun üçün bütün ölkələrdə standartlar qəbul edilmişdir.

Onənəvi olaraq müxtəlif metodlarla müqayisədə şəxsiyyətin identifikasiyası üzrə biometrik metodlar bir sıra üstünlüklərə malikdir [6]:

- biometrik əlamətləri saxtalaşdırmaq çox çətindir;

- biometrik əlamətlərin unikallığına görə identifikasiyanın etibarlılığı çox yüksəkdir;

- biometrik identifikatorı parol kimi unutmaq olmaz və ya plastik kart kimi itirmək olmaz.

Təhlükəsizliyi kəmiyyətcə qiymətləndirmək çox çətindir. Terror təhlükəsinin artması və təhlükəsizliyin təmin olunması sistemlərinin təkmilləşdirilməsi ehtiyacı ona gətirib çıxartmışdı ki, biometrik avadanlıqlar bazarının həcmi son zamanlar sürətlə artmağa başlamıșdır. Biometrik sistemlərin ən böyük sifarişçisi yalnız ticarət müəssisələri deyil, həm də dövlət idarələridir. Xüsusi diqqət insanların kütləvi nəzarət sistemlərinə ehtiyac duyulduğu yerlərə -aeroportlar, stadionlar və başqa obyektlərə ayrılır.

İstənilən insanın üzünün elementləri onun fərdi biometrik xarakteristikalarıdır. Sənədlərdə olan şəkillərdən identifikasiya üçün çox geniş istifadə olunur və bunun üçün bütün ölkələrdə standartlar qəbul edilmişdir.

Fotolar üzrə biometrik identifikasiyanın vacib üstünlükləri vardır və onlar aşağıkakılardır:

$>\quad$ İdentifikasiya zamanı foto və ya şəxsin üzünün video təsvirləri subyektlə bilavasitə əlaqəni tələb etmir və məxfi hesab edilə bilər;

$>$ fotoların verilənlər bazaları başqa biometrik verilənlər bazalarıyla müqayisədə tamdır və bu geniş yayılmışdır;

$>$ göstərilən texnologiyanın tətbiqi dövlət qanunvericiliyinə ciddi dəyişikliklərin daxil edilməsi ilə bağlı deyildir; 


\section{"Informasiya tohlükosizliyinin aktual problemlori" \\ III respublika elmi-praktiki seminarı, 08 dekabr 2017-ci il}

$>$ unikallıq və insanın anadangəlmə bioloji parametrlərinin nisbətən sabit olması və $\mathrm{s}$.

Hesablama buludları bazarda yeni texnologiyadır və müxtəlif sahələrdə istifadə edilməsinin öz üstün cəhətləri vardır. Qeyd edildiyi kimi, hesablama buludlarında istifadəçi internetdən istifadə edərək istənilən yerdən öz fayllarına və ya məlumatlarına giriş əldə edə bilir. Hesablama buludlarının üstün cəhətləri vardır, belə ki, xərclərin azalmas1, təhlükəsizliyin təmin olunması və $\mathrm{s}$.

Hesablama buludlarının üstün cəhətləri [7]:

1. İs görmə qabiliyyətinin üstün olması. Hesablama buludlarında daha az sayda işçilərlə qısa vaxt ərzində çox iş görülür;

2. Xərclərin azaldılması. Hesablama buludlarında istifadəçi kompüter avadanlığını, proqram təminatını və məlumatları bir neçə hissəyə bölür, buna görə də avadanlığa və ya proqram təminatına artıq pul xərcləməyə ehtiyac qalmır;

3. Olyetənliyin sadə olması. İstifadəçi internet vasitəsilə hesablama buludlarında olan məlumatlara və fayllara istənilən vaxt istənilən yerdən giriş edə bilir;

4. Daha az təlim tələb olunur. Hesablama buludlarında görülən iş üçün daha az işçi tələb olunur.

Milli Standartlar və Texnologiyalar İnstitutu (National Institute of Standard and Technology, NIST) hesablama buludunu dörd əsas xarakteristikayla təsvir edir [8]:

- $\quad$ tələbə görə özünəxidmət;

- $\quad$ şəbəkəyə geniş girişin təmin olunması;

- $\quad$ elastikliyin təmin edilməsi;

- resursların birləşdirilməsi və $\mathrm{s}$.

IDC-in verdiyi məlumata görə hesablama buludlarının da öz problemləri vardır. Bunlara təhlükəsizlik, səmərəlilik və s. kimi xüsusiyyətlər aiddir. İcazəli istifadəçinin identifikasiyası üçün xüsusi olaraq təhlükəsizliyin problemlərini aradan qaldırmaq üçün, şəxslərin sifətinin tanınması (Face Recognition System, FRS) sistemindən istifadə olunur [9]. Bu tipli sistemlər də müxtəlifdir və hər birinin özünəməxsus müəyyən funksiyası vardır. Təyinatından asılı olaraq sifətin tanınması prosesi işlənilmiş müxtəlif metod və alqoritmlər vasitəsilə yerinə yetirilir. $\mathrm{Bu}$ sistemlərin də üstün və çatışmayan cəhətləri vardır. Məsələn, insanın tanınması üçün gözün torlu qişasından istifadə edildikdə yüksək dəqiqlik və tanımanın sabitliyi təmin edilir, amma bunun üçün bahalı avadanlıq və əlavə xərclər tələb olunur.

\section{HESABLAMA BULUDLARINDA İNSANIN SİFT TOSVIRLORINO ӘSASØN TANINMASI METODLARININ ANALIZİ}

Son dövrdə şəxslərin üzlərinə görə tanınması (Face Recognition, FR) üzrə biometrik texnologiyaların müxtəlif sahələrə tətbiqi geniş vüsət alıb və buda müxtəlif proqram təminatlarının təkmilləşdirilməsini tələb edir. Böyük məlumatların, hesablama buludlarının, sosial şəbəkələrin və maşın təliminin analizi sahəsindəki tədqiqatlar göstərdi ki, Computer Vision-da belə ciddi problemlərin öhdəsindən gəlmək olar. Buna görə [9] işində sifətin tanınmasına müasir nöqteyi-nəzərdən - Cloud Computing, Big Data, sosial şəbəkələr və maşın təlimi konsepsiyalarına baxılıb və Ekstremal Təlim Maşınları (Extreme Learning MachinesELM) texnikasına əsaslanan FR yanaşması üçün yeni metod təklif edilib. Buna misal olaraq böyük məlumatlarla işləyən sosial şəbəkələr üçün üz teqləri (Face Tagging, FT) və s. metodları göstərmək olar. Təklif edilən yanaşmada yuxarıda göstərilən konsepsiyaların uyğun xüsusiyyətləri birləşir, bu da onun səmərəliliyini artırır.

[10] işində radial bazis funksiyalarının (Radial Basis Function, RBF) yeni modifikasiyaları və şəxsin statik universal üz ifadəsinin altı təsvirindən istifadə etməklə onun bütöv tanıması üçün neyron şəbəkə əsasında yeni metod təqdim edilmişdir. Buludlu bazis funksiyası (Cloud Basis Function, CBF) adlandırılan yeni bazis funksiyaları siniflərin diskriminasiyasıyla bağlı xüsusiyyətlərini qeyd etmək üçün müxtəlif çəki əmsalından istifadə edir.

Hesablama buludunun artan perspektivli potensialı səhiyyə üçün bir sira buludlu sistemlər və xidmətlər hazırlamağa icazə verdi. Hesablama buludları tibb işçilərini məsafə baxımından pasiyentlərin sağlamlığına nəzarət etmək üçün smart-portativ qurğulara uyğunlaşmağa vadar etdilər. Bu məqsədlə yaşl1 insanların sağlamlığının monitorinqi üçün nitqin və şəxsin üzünün tanınması üçün yeni buludlu sistem təklif edildi, belə $\mathrm{ki}$, videokameralar şəxslərin üzlərinin təsvirlərlə birlikdə nitqini də yı̆̆ır və analiz və təsnifat üçün buludun serverinə çatdırır [11].

Monitorinq və müşahidə sistemində insanların izlənilməsi adətən əşyaların interneti (Internet-of-Things, IoT) qurğularından məlumatların böyük həcminin əldə edilməsinə səbəb olur. Şəxslərin üzlərinin tanınması hesablama buludlarında yerinə yetirilir, belə ki, onlar müşahidə kameralarının yanında yerləşdirilir, buda emal mərkəzinə kütləvi məlumatların ötürülməsi ehtiyacını yaradır. Digər tərəfdən, şəxslərin üzlərinin müqayisəsi prosesi buludlu mühitdə şəxsin üzünün vektor-funksiyadan istifadə edilməklə yerinə yetirilir, buda işin keyfiyyətinin yüksəlməsinə səbəb olur [12].

Şəxslərin üzləri çox mürəkkəb və dinamik obyektlərdir, belə ki, onlardan şəxslərin tanınmasında biometrik elementlər kimi istifadə olunur. Son zamanlar biometrik sistemlər təhlükəsizliyin təmin olunmasında özünü doğrultdu, belə ki, istifadəçinin siyahıda qeyd olunanlarla müqayisəsi və tanınması hər gün yerinə yetirilir. $\mathrm{Bu}$ prosesi asanlaşdırmaq üçün, təşkilatların böyük hesablama vasitələrindən istifadə etməklə bunları dəstəkləməsi lazımdır. Bəzi işlərdə hesablama buludlarından istifadə etməklə şəxslərin üzlərinə görə tanınması üçün əsas komponentlərin analzi (Principal Component Analysis, PCA) üsulundan istifadə edilmişdir, belə ki, böyütmə-inversiya funksiyasının transformasiyasından (Scale-İnvariant Feature Transform, SIFT) istifadə edərək invariant nöqtələrin miqdarını azaltmaqla bu iş həyata keçirilmişdir [13].

Şəxslərin üzlərinə görə tanınması təhlükəsizliyin təmin olunmasının əhəmiyyətli mövzusundan biridir. Hal-hazırda bu 


\section{"Informasiya tohlükosizliyinin aktual problemlori" \\ III respublika elmi-praktiki seminarı, 08 dekabr 2017-ci il}

sahədə monitorinqin keçirilməsinə böyük diqqət yetirilir. Hazırda bəzi məqalələrdə sənəddə olan şəxslərin üzlərinə görə tanınması üçün aparılan monitorinqin buludlu sistemdə olması təklif edilir. $\mathrm{O}$ aşkar etmə və şəxslərin üzlərinin tanınması və məlumatların vizuallaşdırması üçün hesablama buludlarının modulu üçün monitorinqin müştəri modulundan ibarətdir. $\mathrm{Bu}$ halda Gabor-un mərkəzləşdirilmiş əlamətlərin ikiqat şablona ayrılmasının lokal metodu təklif edilir. Bu metod əhəmiyyətli lokal funksiyaları dəstəkləyir, Gabor filtrinin çətinliyini azaldır və tekstur haqqında dövri dəyişməzliyi və daha dəqiq informasiya verir [14].

Bəzi tədqiqatlarda hesablama buludlarından istifadə edilməklə mobil proqramlar üçün yüklənmənin azaldılması üçün SmartRank yanaşması təqdim edilmişdir. Hesablama buludlarının göstəricilərinin köməyi ilə resursların qiymətləndirilməsi əsasında simvolların tanınması üçün bu yanaşmadan istifadə olunmuşdur. Qiymətləndirmə üçün başqa üsullardan da istifadə olunur. Bunlardan biri də Markov zəncirindən istifadə etməklə həyata keçirilmişdir [15].

[16] işində buludlu robot sisteminin hazırlaması və tətbiqi məsələlərinə baxılmışdır. Belə ki, paylanmış hesablama resurslarına giriş üçün hesablama buludlarının infrastrukturu ilə əlaqə yaradılır və çoxməsələlik: sifətin aşkarlanması, tanınması və s. yerinə yetirilir. Şəxslərin üzlərinin tanınması və s. məsələr üçün Cloud Robot System-dən (CR) istifadə edilmişdir. Eksperimental nəticələr göstərmişdir ki, avtomatlaşdırılan robot sistem olan RC məsələləri effektiv həll etməyi bacarır.

Beynəlxalq verilənlər korporosiyasının (International Data Corporation, IDC) analitik mərkəzi informasiya texnologiyaları (İT) üzrə təhlil aparır və proqnozlar verir. Mərkəzin 2016-c1 ildə verdiyi proqnoza görə hesablama buludlarının yaradılmasına sərf olunan xərclər 101 milyarddan 2020-ci ildə 213 milyard dollaradək artacaq [17] (şəkil 1).

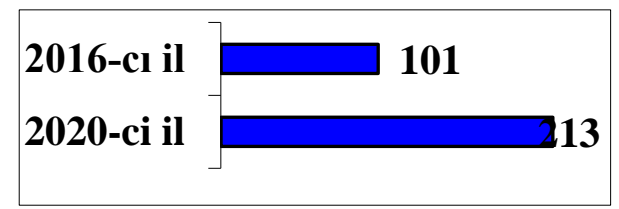

Şəkil 1. Hesablama buludlarının yaradılması xərclərinin proqnozu (mlrd. \$)

\section{NəTICə}

Məqalədən göründüyü kimi hesablama buludlarında istifadəçilər üçün biometrik autentifikasiya üsullarından istifadə edilməsi təhlükəsizliyin təmin olunmasında mühüm rol oynayır. Qeyd etmək olar ki, AMEA İnformasiya Texnologiyaları İnstitutunda da hesablama buludlarından istifadə olunur. Hesablama buludlarında böyük həcmli məlumatlar saxlanılır. Başqa məsələlərdə olduğu kimi burada da ən böyük problemlərdən biri istifadəçilərin təhlükəsizliyinin təmin olunmasıdır. Gələcəkdə istifadəçilərin hesablama buludlarına girişinin təhlükəsliyini təmin etmək üçün müxtəlif biometrik autentifikasiya texnologiyalarından, o cümlədən sifət təsvirlərinə görə tanınma sistemlərindən istifadə edilməsi məqsədəuyğundur. Hesablama buludlarında biometrik autentifikasiya texnologiyalarından istifadə olunması istifadəçilərin təhlükəsizliyinin təmin olunmasında mühüm rol oynaya bilər və bu da işin səmərəliliyinin artmasina səbəb olar.

\section{ӘDӘBIYYYT}

[1] D. Castro, "How Much Will PRISM Cost the U.S. Cloud Computing Industry?", The information technology and innovation foundation, 2013, 9 p.

[2] A.P. Akshay, P.P. Vrushsen, "Face Recognition System (FRS) on Cloud Computing for User Authentication", International Journal of Soft Computing and Engineering (IJSCE), 2013, vol. 3, issue 4, pp. 189-192.

[3] J.Q. Li, L.X. Huang, Y.M. Zhou, S.Q. He, Z. Ming, "Computation Partitioning for Mobile Cloud Computing in a Big Data Environment", IEEE transactions on industrial informatics, 2017, vol. 13, no. 4, pp. 2009-2018.

[4] M. Ayad, M. Taher, A. Salem, "Real-Time Mobile Cloud Computing: A Case Study in Face Recognition", 28th International Conference on Advanced Information Networking and Applications Workshops, 2014, pp. 73-76.

[5] K. Sun, H. Kang, HH. Park, "Tagging and classifying facial images in cloud environments based on KNN using Map Reduce", OPTIC, 2015, vol. 126, no. 21, pp. 3227-3233.

[6] T. Kazımov, Ş. Mahmudova, "İnformasiya təhlükəsizliyinin təmin olunmasında biometrik texnologiyaların rolu”, İnformasiya təhlükəsizliyinin multidissiplinar problemləri üzrə II respublika elmipraktiki konfrans1, 14 may 2015-ci il, səh. 218-221.

[7] A.P. Akshay, P.P. Vrushsen, "Face Recognition System (FRS) on Cloud Computing for User Authentication", International Journal of Soft Computing and Engineering (IJSCE), 2013, vol. 3, issue 4, pp. 189-192.

[8] "The NIST Definition of Cloud Computing". National Institute of Science and Technology (NIST), 2011, 7 p.

[9] A. Vinay, V.S. Shekhar, J. Rituparna, T. Aggrawal, K.N.B. Murthy, S. Natarajan, "Cloud Based Big Data Analytics Framework for Face Recognition in Social Networks using Machine Learning", Procedia Computer Science, 2015, vol. 50, pp. 623-630.

[10] C.R. De Silva, S. Ranganath, L.C. De Silva, "Cloud basis function neural network: A modified RBF network architecture for holistic facial expression recognition", Pattern recognition, 2008, vol. 41, pp. 12411253.

[11] M. S. Hossain, G. Muhammad, "Cloud-Assisted Speech and Face Recognition Framework for Health Monitoring", Mobile networks \& applications, 2015, vol. 20, no. 3, pp. 391-399.

[12] H.M. Amin, N.M. Ahmad, M.M. Ali, 2016 IEEE Region 10 symposium (tensymp), Book: IEEE, 2016, pp. 119-124.

[13] D.R. Kisku, S. Rana, "Multithread Face Recognition in Cloud", Journal of sensors, 2016, pp. 1-21.

[14] C. Li, W. Wei, J.X. Li, W. Song, "A cloud-based monitoring system via face recognition using Gabor and CS-LBP features", Journal of supercomputing, 2017, vol. 73, no. 4, pp. 1532-1546.

[15] F.A. Silva, P. Maciel, E. Santana, R. Matos, J. Dantas, "Mobile cloud face recognition based on smart cloud ranking", Computing, 2017, vol. 99, no. 3, pp. 287-311.

[16] Sh. Tian, S. G. Lee, "Face Recognition System for Cloud Robot", Advanced Science and Technology Letters, 2015, vol. 98, pp. 46-48.

[17] F. Gens, Worldwide and Regional Public IT Cloud Services Forecast, 2016-2020, 2016, 37 p. 
ANALYSIS OF BIOMETRIC AUTHENTICATION METHODS FOR ENSURING SECURITY USERS IN CLOUD COMPUTING

Shafagat Mahmudova

Institute of Information Technology of ANAS, Baku, Azerbaijan shafagat_57@mail.ru

Abstract - In modern age cloud computing are widely used in various fields. Ensuring users' security in cloud computing is one of the main problems. In this study, methods of recognition of human face by one of the biometric authentication methods in ensuring security users in cloud computing have been explained. Problems in this field have been investigated.

Keywords - cloud computing, security, authentication, recognition, face images, biometric characteristics 